\title{
Experimental model of cranially pedicled TRAM flap in rats $^{1}$
}

\author{
Elvio Bueno Garcia ${ }^{2}$ \\ Lydia Masako Ferreira ${ }^{3}$ \\ Miguel Sabino Neto ${ }^{4}$ \\ Natasha Sallum ${ }^{5}$
}

\begin{abstract}
Garcia EB, Ferreira LM, Sabino Neto M, Sallum N. Experimental model of cranially pedicled TRAM flap in rats. Acta Cir Bras [serial online] 2004 Vol 19 Special Edition. Available on URL: http://www.scielo.br/acb.

ABSTRACT - In a simple, reproducible, and non-expensive experimental model the transverse rectus abdominis muscle (TRAM) flap has been described in male, adult Wistar rats (Rattus norvegicus albinus, Rodentia, Mammalia), weighing approximately $300 \mathrm{~g}$, at the central biotery of the Federal University at São Paulo, Paulista Medical School (UNIFESP - EPM). This article describes the use of a cranially based pedicled rectus abdominis muscle flap sling, unilaterally to the right, with the purpose to better understand the pathophysiology of and the research on new treatments to prevent partial or total flap necrosis. This experimental model sponsors quite a number of studies to be conducted to assess the effects of different drugs of physical methods on the feasibility of standard, cranial monopedicled TRAM.As a standard model, it also harbors the comparison among results from different studies.
\end{abstract}

KEY WORDS - Rats. TRAM flap. Tissue Survival. Models, Animal.

\section{Introduction}

High incidence of cancer associated to physical and psychological traumas resulting from mamary ablation were the key reasons driving medical and scientific communities to search for new diagnosis methods, more conservative treatment, and tactical and technical repair solutions, turning mamary reconstruction an integral part of sistematization in mamary cancer treatment. ${ }^{1}$

Among major advances in mamary reconstruction, post-mastectomy of transverse rectus abdominis muscle (TRAM) stands out, since it harbors the possibility of managing large amounts of tissue volume with acceptable scars in the donor region. Additionally, it has been the first choice at different services working on reconstruction ${ }^{2,3}$.

\section{Work carried out at the Laboratories of the Federal University of São Paulo (UNIFESP) PhD, Interim Professor, Plastic Surgery, Surgery Department at the Federal University of São Paulo (UNIFESP-EPM) Titular and Head Professor, Plastic Surgery, Surgery Department at the Federal University of São Paulo (UNIFESP-EPM)


Post-mastectomy TRAM flap may be mono or bipedicled to the transverse rectus abdominis muscle where blood supply is based in the upper epigastric artery, or through a micro surgical flap based on lower epigastric artery: the best vascular support for the flap.

Opposingly to what occurs with human beings, TRAM flap in rats reports better vascular supply when pedicled upperly by cranial epigastric artery. Different authors in search of TRAM ischemic models in rats have tried to carry out pecicles inferiorly, in caudal epigastric artery, as Ely ${ }^{4}$.

While trying to optimize the use of flap, many authors have tried to study variants which include the use of: one or more abdominal recti as pedicle; drugs to influence flap perfusion and survival time; the use of prior flap autonomization and its variants in the time span between autonomization and definitive surgical procedure.

\section{Proposition}

The purpose of the present study is to report on and to make available the use of TRAM flap in rats so that investigation can be carried out on presence or the absence of post-operative tissue necrosis. The flap may be obtained through the use of one or more abdominal recti as pedicle. The present article describes cranially based pedicled rectus abdominis muscle flap sling, unilaterally to the right.

\section{Method description}

In the pre-operative stage the rats are selected, lodged in individual cages, weighed and kept under no feeding restriction up to study time.

The present model used male, adult Wistar rats (Rattus norvegicus albinus, Rodentia, Mammalia) weighing approximately 300 grams, from at the Federal University at São Paulo, Paulista Medical School (UNIFESP - EPM) central biotery.

The rats must be lodged and kept in individual cages, under controlled conditions, with feed and water ad libitum.

Anesthesia is to be carried out through ethyl ether inhalation in a bell glass.

For surgical procedures, rats must be placed dorsally, immobilized on a flat surface, with limbs extended, and depilated by manual traction. Antisepsis is to be carried out with iodated alcohol at $2 \%$, and the surgical field is to be circumscribed by sterilized cloth. The TRAM flap is then outlined: 3 x $5 \mathrm{~cm}$. Surgical procedures illustrations are the following (FIGURES 1-8).

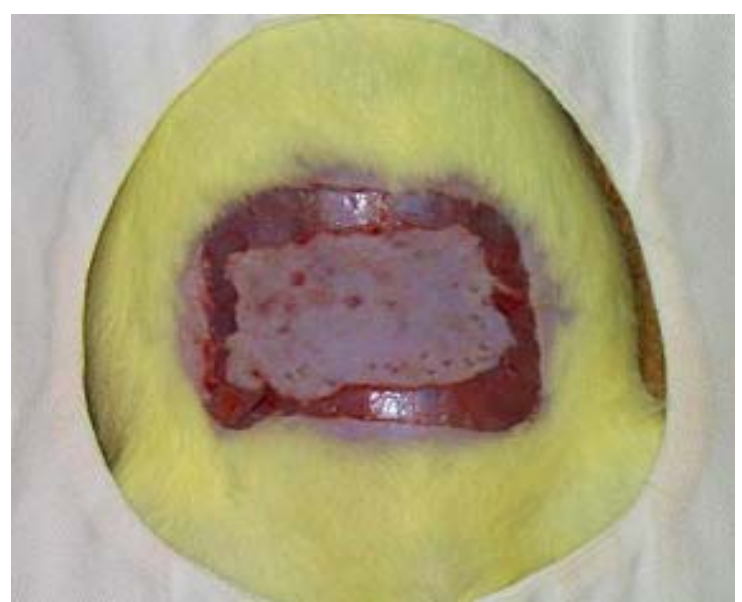

FIGURE 1: Skin incision and carneous panniculus all over circumscribed area. 


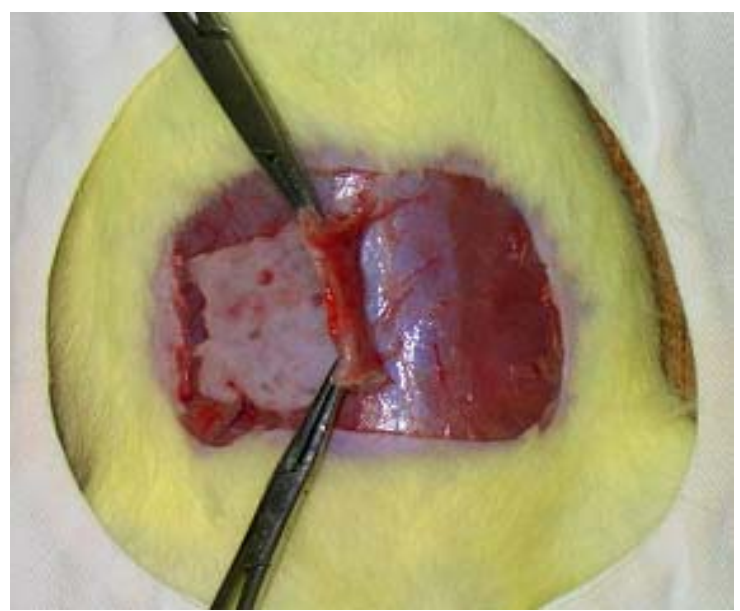

FIGURE 2: Dissection of flap contralaterally to pedicle up to Linea Alba.

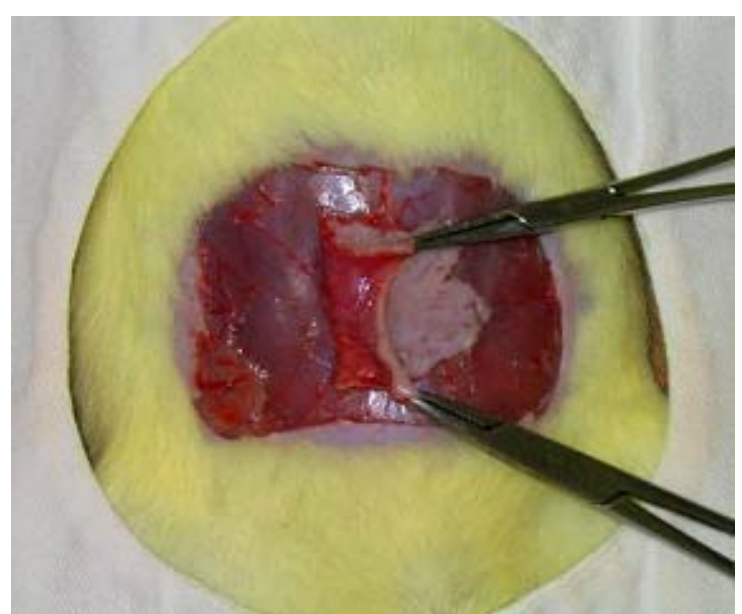

FIGURE 3: Dissection of flap ipsilaterally to pedicle up to lateral margin of rectus abdominis muscle.

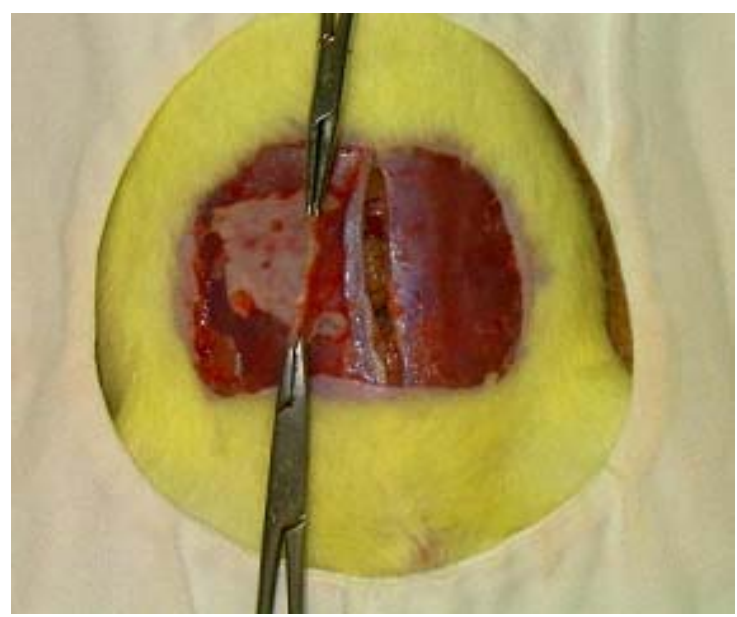

FIGURE 4: Longitudinal incision in Linea Alba aponeurosis. 


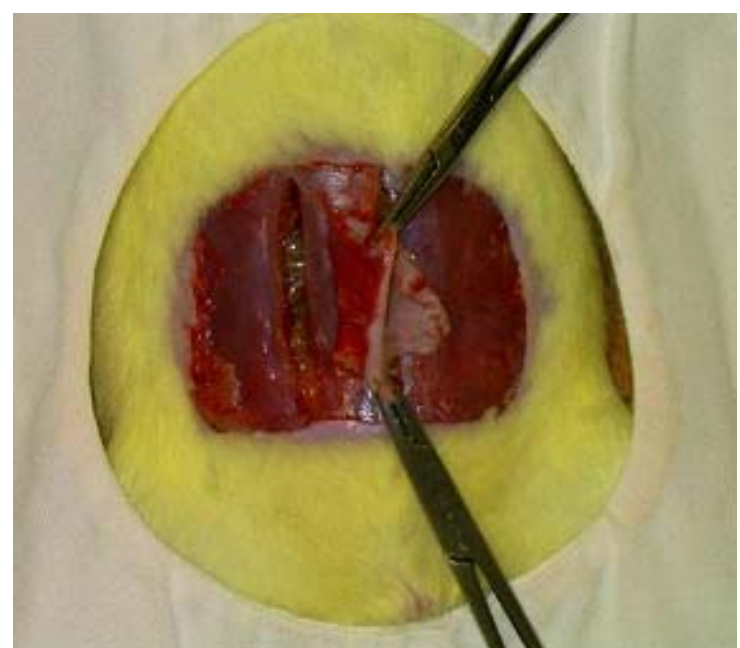

FIGURE 5: Longitudinal incision in the lateral margin of the chosen muscle.

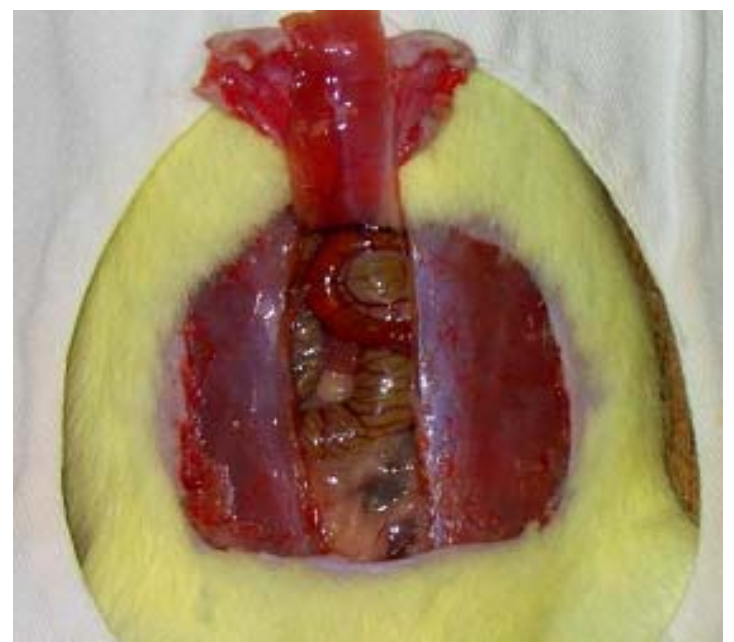

FIGURE 6: The incision completed by sectioning of the muscular pedicle to be discarded (in this case, caudal) with subsequent flap release.

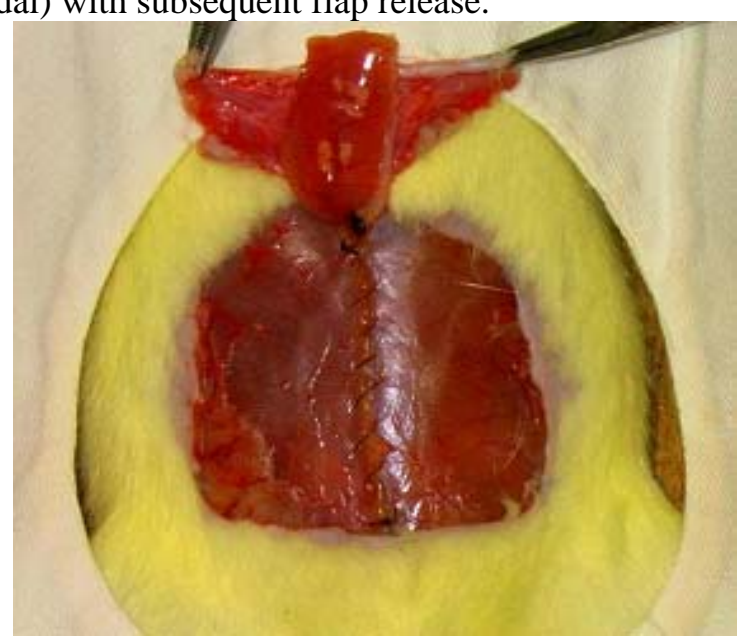

FIGURE 7: Suture of aponeurotic plane with monofilamentar nylon 5.0 thread without stressing the pedicle of chosen flap. 


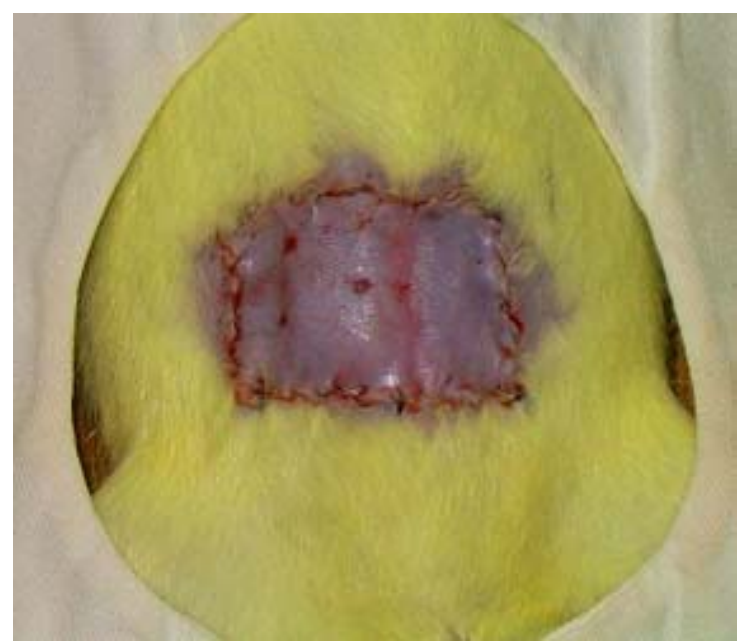

FIGURE 8: Sutura of flap skin in its original position, also using monofilamentar nylon5.0.

\section{Perspectives}

The use of this simple, reproducible, non-expensive experimental model can be seen as a practical way for a better understanding of the pathophysiology of and research on new treatments to prevent partial or total flap necrosis: a complication that may prove hard to manage. The experimental model harbors a number of studies to assess the effect of different drugs or physical methods on standard, monopedicled cranial TRAM flap feasibility in rats. As a standard model it also harbors comparison among results from different studies.

\section{References}

1. Garcia EB, Sabino Neto M, Ferreira LM - Thoracia-axillary flap in immediate breast repair after upper lateral quadrantectomy Rev Bras Mastol. 2000; 10: (4):185-91.

2. Shestak KC - Breast reconstruction with pedicled TRAM flap. Clin Plast Surg. 1998;25:167-82.

3. Veiga D F, Sabino Neto M, Garcia E B, Ferreira LM - Evaluations of aesthetic results and patients satisfaction with the late pedicled TRAM flap breast reconstruction. Ann Plast Surg. 2002; 48:515-20.

4. Ely PB, Miltersteiner AR, Hoff FC - Retalho miocutâneo transverso de músculo reto abdominal (TRAM flap) - modelo experimental em ratos. Acta Cir Bras. 1997; 12: 75.

5. Hartrampf CR, Scheflan M, Black PW - Breast reconstruction with a transverse abdominal island flap. Plast Reconstr Surg. 1982; 69: 216-24.

6. Gandolfo E - A breast reconstruction with a lower abdominal myocutaneous flap. Br J Plast Surg. 1982; 25: 452-7.

7. Ishii CH, Bostwick J, Rainet TJ, Coleman J, Jhester TR - Double pedicle transverse rectus abdominis myocutaneous flap for unilateral breast and chest wall reconstruction. Plast Reconstr Surg. 1985;76: 901-7.

8. Özgentas HE, Shena, QS, Spira M - Development of a tram flap model in the rat and study of vascular dominance. Plast Reconstr Surg. 1994; 94: 1012-7.

9. Özgentas HE, Shena QS, Spira M - Study of the delay phenomenon in the rat TRAM flap model. Plast Reconstr Surg. 1994; 94: 1018-24.

10. Hallock GG, Rice DC - Evidence for the efficacy of TRAM flap delay in a rat model Plast Reconstr Surg. 1995; 96: 1351-7. 
11. Sasaki GH, Pang CY - Hemodynamics and viability of acute neurovascular island skin flaps in rats. Plast Reconstr Surg. 1980; 65:152-8.

Garcia EB, Ferreira LM, Sabino Neto M, Sallum N. Modelo Experimental do retalho TRAM com pedículo cranial em ratos. Acta Cir Bras [serial online] 2004 Vol 19 Edição Especial. Disponível em URL: http://www.scielo.br/acb.

RESUMO - Em um modelo experimental simples, reprodutível e não oneroso, descrevemos o Retalho Músculo-cutâneo Transverso de Músculo Reto do Abdome (TRAM flap), em rato Wistar (Rattus norvegicus albinus, Rodentia, Mammalia), macho, adulto com peso aproximado de $300 \mathrm{~g}$, procedente do biotério central da UNIFESP - EPM. O presente artigo descreve o retalho de base cranial com o pedículo no músculo reto do abdome, unilateral à direita, com objetivo de proporcionar um melhor entendimento da fisiopatologia e pesquisa de novos tratamentos que previnam a necrose parcial ou total do retalho. Este modelo experimental permite realizar inúmeros estudos, avaliando o efeito de diferentes drogas ou métodos físicos sobre a viabilidade do retalho TRAM monopediculado de pedículo cranial padrão. Sendo um modelo padronizado admite, ainda, a comparação entre resultados de diferentes estudos.

DESCRITORES - Ratos. Retalho TRAM. Modelos Animais. Sobrevivência tecidual.

Conflito de interesse: nenhum Fonte de financiamento: nenhum

Correspondence:

Elvio Bueno Garcia

UNIFESP-EPM, Plastic Surgery Division, Surgery Division

Rua Napoleão de Barros, 715, $4^{\circ}$ andar

CEP 04024-900 São Paulo - SP

Tel: (11) 5576.4118 Fax: (11) 5571.6579

sandra.dcir@epm.br

elvio@uol.com.br 